\title{
Multiple Compensation Consultants and CEO Pay
}

\author{
Rezaul Kabir \\ University of Twente \\ r.kabir@utwente.nl \\ Marizah Minhat \\ Edinburgh Napier University \\ m.minhat@napier.ac.uk
}

September 2010

JEL classification: G34, J33, M52

Keywords: Executive compensation, CEO pay, Compensation consultant, Corporate governance

\begin{abstract}
We are very grateful for numerous helpful comments and suggestions from an anonymous referee, Kevin Campbell, Martin Conyon, Amir Amel-Zadeh, Ruth Bender, Chris Veld and participants at the 2008 Multinational Finance Society Conference in Orlando (USA), the 2009 European Financial Management Symposium on Corporate Governance and Control in Cambridge (UK), the 2009 International Executive Remuneration Workshop in Cambridge (UK), the 2010 European Accounting Association Annual Conference in Istanbul (Turkey) and the 2010 Academy of Management Annual Meeting in Montreal. All remaining errors are ours.
\end{abstract}




\begin{abstract}
The study examines the practice of employing multiple compensation consultants. Data for a sample of UK companies over the period 2003-2006 are analyzed using a variety of econometric methods. We find that CEOs receive higher equity-based pay when firms employ more than one compensation consultant. Further, an increase in the number of compensation consultants is associated with an increase in CEO pay, whereas no decline in CEO pay takes place when firms reduce the number of pay consultants. We also observe that the market shares of compensation consultant are positively related to CEO compensation. The finding is consistent with the conjecture that compensation consultants act to survive competition from other consultants.
\end{abstract}




\section{Introduction}

The adoption of compensation consultants in the executive pay setting process has become a widespread practice in the corporate world. Pay consultants are frequently hired by a firm's compensation/remuneration committee which is responsible for the design of Chief Executive Officer's (CEO) pay package, but does not have adequate skill and knowledge about it. $^{1}$ Due to a lack of adequate disclosure, the empirical evidence has so far been scarce on how the practice of employing compensation consultants influences executive pay.

Recently, several studies demonstrate that CEOs of firms that employ compensation consultants receive higher pay relative to those who do not employ any consultant (Cadman, Carter and Hillegeist, 2010; Conyon, Peck and Sadler, 2009; Armstrong, Ittner and Larcker, 2008; Voulgaris, Stathopoulos and Walker, 2008). One notable phenomenon in this regard is that many firms seek recommendations from not just one but several compensation consultants. Analyzing a sample of 1046 US firms, Murphy and Sandino (2010) find that 181 firms (17\%) use two or more compensation consultants. Conyon et al. (2009) report that while most US firms use only one compensation consultant, UK firms often use more than one pay consultant. The interesting question that has remained unanswered is whether CEO compensation increases or decreases when a firm employs more than one compensation consultant. The first purpose of our study is to conduct an empirical investigation of this issue.

\footnotetext{
${ }^{1}$ See, for example, Anderson and Bizjak (2003) and Sun, Cahan and Emanuel (2009) for a discussion on the functioning and quality of compensation committees.
} 
Although there is no requirement for firms to disclose the costs of employing compensation consultants, anecdotal evidence suggests that these consultants do not come cheap (they charge about $£ 500-£ 800$ an hour for their services). ${ }^{2}$ Murphy and Sandino (2010) observe that the average pay consulting fee paid in 2006 for a sample of Canadian companies was almost US\$90,000. If a consultant does not come cheap, then it poses the question: why firms use these costly multiple compensation consultants? The usual assumption is that compensation consultants provide independent recommendations and a variety of pay related proprietary information. Using the 'efficient contracting' view of executive pay, Armstrong et al. (2008) and Conyon et al. (2009) argue that consultants can help remuneration committees to design an appropriate level and structure of CEO compensation and thus align the interests of CEOs with those of shareholders. Bender (2008) suggests that if different compensation consultants specialize in different aspects of pay, firms can benefit from employing multiple consultants.

On the other hand, Cadman et al. (2010) and Murphy and Sandino (2010) report that compensation consultants face severe conflicts of interests because they provide client firms additional types of lucrative advisory services (for example, employee benefits/pensions and actuarial services). Bebchuk and Fried (2003) argue that compensation consultants have therefore strong incentives not to displease incumbent CEOs who otherwise would opt to hire a new consultant. Consequently, pay consultants would recommend higher CEO pay rather than risk losing their business to other competitors. Among firms employing one compensation consultant, there is an inherent competition from other consultants to attract new business opportunities whereas among

\footnotetext{
${ }^{2}$ For example, see, 'Get me an above-average pay consultant', The Mail on Sunday (February 6, 2005), and 'Pay consultants are next in line for a pummelling', The Sunday Times (March 8, 2009).
} 
firms with multiple consultants, the contest is also towards retaining the existing business. This feature leads us to the second purpose of the study: to investigate if compensation consultants act in order to survive competition from other consultants.

We undertake a detailed empirical analysis of compensation consultants by examining a sample of UK firms for the years 2003-2006. The study is of particular interest because each and every firm in our sample uses at least one compensation consultant and more than half of these firms employ multiple consultants. But, we know relatively little about whether shareholders of firms derive additional benefit from employing two or more pay consultants. Although prior studies (e.g. Cadman et al., 2010; Conyon et al., 2009; Voulgaris et al. 2008) examine whether firms with compensation consultants in general pay their CEOs more relative to those who do not employ any pay consultant, we are not aware of any study that specifically investigates the issue of multiple compensation consultants.

Another distinct feature of the study is that whilst concurrent studies examine compensation consultant data for one year only, ours analyze data covering several consecutive years. In contrast to US firms which had to disclose consultant related information with effect from December 2006, UK firms started providing this information several years earlier. The use of panel data taking into account both timeseries and cross-sectional variability thus allows us to undertake a more comprehensive and statistically reliable empirical analysis. An additional novelty is that we study how CEO compensation changes when firms decide to increase or reduce the number of pay consultants from one year to another. 
We present two new findings to the extant literature. First, we observe that CEO equitybased pay increases when firms rely on a higher number of compensation consultants. The finding holds after controlling for different firm, corporate governance and CEO characteristics. In particular, we find that an increase in the number of compensation consultants is associated with an increase in CEO compensation. But, there is no corresponding decline in CEO compensation when firms reduce the number of pay consultants. Second, we document that competition among compensation consultants leads to an increase in CEO pay. Specifically, we find that the market share of compensation consultants is significantly positively related to client firm's CEO pay. The finding supports the conjecture that by advising towards higher pay, compensation consultants try to secure their business interests with the client firm and thereby survive from competition. All our empirical results are robust to a variety of econometric analyses that controls for different firm-specific, CEO-specific and corporate governance factors.

The remainder of this paper is structured as follows. Section 2 outlines the two research questions of the study. Section 3 describes the research method. A description of data is presented in Section 4 while the empirical results of the study are presented in Section 5. Finally, Section 6 presents summary and conclusions.

\section{Research questions}

The practice of employing executive compensation consultants has come under academic scrutiny only recently. The role of compensation consultants can be analyzed using two theoretical perspectives (Bebchuk and Fried, 2003; Armstrong et al., 2008). 
According to the efficient or optimal contracting view, compensation consultants provide expert advice and useful information that help the Board of Directors to design an optimal structure of executive compensation so that greater manager-shareholder interest alignment can take place. In this context, the compensation consultant is deemed to act in the best interest of shareholders. On the other hand, according to the rent extraction or managerial power view, compensation consultants have strong incentives to help CEOs in receiving higher pay because it ensures continuity of their business relationships with client firms. In turn, CEOs can use their power to select and appoint those consultants who looked after their personal welfare.

Wade, Porac and Pollock (1997) argue that a firm's compensation committee usually validates high levels of executive compensation by citing a compensation consultant as advisor in the pay-setting process. Managerial rent extraction is further facilitated by employing multiple compensation consultants as firms try to justify higher CEO pay. Firms create an impression to the outside world that the decision on CEO compensation has been made by seeking advice from different consultants. Crystal (1991) observes that whenever a CEO is paid above the average, the company and consultants try to provide a justification of it. Anecdotal evidence also indicates that remuneration committees favor seeking advice from several compensation consultants in order to find the highest rate of pay for CEOs. ${ }^{3}$ However, this issue has not yet been examined in the academic literature. Therefore, the first research question we investigate is whether CEOs receive higher compensation when firms employ multiple pay consultants.

\footnotetext{
${ }^{3}$ The Sunday Telegraph (Jan. 4, 2004): 'UK companies splurge on pay consultants'.
} 
Our second research question relates to the compensation consultants' pursuit for market shares and its relation with client firm's CEO pay. Numerous compensation consultants are competing for both compensation and non-compensation related businesses. Recent studies (Cadman et al., 2010 and Murphy and Sandino, 2010) document that compensation consultants aim to secure additional (non-compensation related) businesses with the client firm. These businesses include providing consultancy on human resource management, internal control, insurance, financial and risk management. Apart from seeking additional businesses, compensation consultants also want to ensure the continuity of pay consulting business with the existing client firm.

It is therefore almost impossible for compensation consultants to advise openly and critically on CEO pay. Crystal (1991) argues that if a consultant's recommendation does not cause the CEO to earn more money, the consultant risks losing business with the client firm. Similarly, Bebchuk and Fried (2003) argue that a recommendation from compensation consultant that displeases a CEO may risk the consultant's future relationships with the firm. The prospect of lucrative business interests incentivize compensation consultants to compete intensely with each other. ${ }^{4}$ To ensure continuity in business, the incumbent consultant needs to recommend CEO pay to a level higher than that could possibly be recommended by other competing consultants. We would therefore observe that, ex post, higher CEO compensation would be associated with consultants having larger market shares.

\footnotetext{
${ }^{4}$ Although Bebchuk and Fried (2003) do not explicitly mention competition among compensation consultants, the prediction that the incumbent consultant might lose business to other consultants implicitly refers to the presence of competition.
} 


\section{Research methods}

To address the first research question, we initially perform a bivariate analysis to examine the simple relationship between compensation consultants and CEO compensation. Firms are classified according to the total number of compensation consultants used. For each category of firms, we then examine the level of CEO compensation. This descriptive analysis provides a preliminary evidence of whether CEO compensation increases when the number of compensation consultants employed by a firm increases.

Then we proceed to a multivariate analysis that controls for a variety of firm-specific, CEO-specific and corporate governance determinants of pay (Conyon et al., 2009; Murphy and Sandino, 2010; Cadman et al., 2010). We first employ the pooled Ordinary Least Squares (OLS) regression technique to investigate if the use of multiple compensation consultants is associated with higher CEO pay. The estimated model is written as follows:

$$
\begin{aligned}
& \text { Pay }_{j t} \\
& =\alpha+\beta_{1} \text { Con }_{j t}+\sum_{2}^{n} \beta_{n} \text { Controls }_{j t}+\lambda_{j}+\delta_{t}+\varepsilon_{j t}
\end{aligned}
$$

The dependent variable $P a y_{j t}$ refers to compensation received by the CEO of company $\mathrm{j}$ at time t. It is defined in several ways. One is the total annual compensation which is made up of the following components: salary, bonus, benefit ${ }^{5}$, pension increment, and

\footnotetext{
${ }^{5}$ This refers mainly to benefits such as car allowance and insurance premium paid on behalf of CEOs.
} 
values of stock grants and stock option grants. The pension increment is derived from the difference between the actuarial values of defined benefit pension from two consecutive years. Stock grant is measured at the value of the equity discounted at $20 \%$ to reflect its performance-contingent character. The Black-Scholes-Merton value of stock option is employed to approximate the value of stock options. The other ways of defining Pay are by considering the amount and proportion of equity-based compensation (the value of stock grants and stock option grants) as well as variable compensation (sum of bonus, shares and stock option grants, and pension increment). ${ }^{6}$ The explanatory variable $\operatorname{Con}_{j t}$ is the total number of compensation consultants used by firm $j$ at time $t$. As a robustness check, we also use another approach whereby a dummy variable is constructed that equals one if a firm uses two (three) or more consultants, zero otherwise.

We use a variety of control variables that are commonly found in the literature to be the key determinants of executive compensation. These include firm characteristics (firm performance, firm size), CEO characteristics (age, tenure) and corporate governance characteristics (institutional ownership, CEO duality, board size, non-executive directors, remuneration committee size). All these variables are defined in the Appendix. For ease of comparison with prior studies, we use annual stock return as the measure of firm performance (Brick et al., 2006). ${ }^{7}$ The regression analysis also includes additional controls for industry $\left(\lambda_{j}\right)$ and year $\left(\delta_{t}\right)$. The remaining term in specification $(1), \varepsilon_{\mathrm{jt}}$, is an idiosyncratic error term.

\footnotetext{
${ }^{6}$ The results from variable pay are similar to those of total pay. Therefore, these results are not reported in the paper but are available from the authors upon request.

${ }^{7} \mathrm{We}$ also use another performance variable, return on assets, as part of robustness check. It is calculated as the ratio of earnings before interest and taxes to total assets.
} 
We perform panel data regressions to supplement the analysis of pooled OLS regressions. The Hausman test shows that random effects model is more appropriate for the data we use than fixed effects model. Therefore, the results of random effects estimations are presented together with the OLS results.

Our second research question is concerned with the association between compensation consultant's market share and CEO pay. The estimated regression model is written as follows:

$$
\begin{aligned}
& \text { Pay }_{j t} \\
& =\alpha+\beta_{1} \text { MarketShare }_{j t}+\sum_{2}^{n} \beta_{n} \text { Controls }_{j t}+\lambda_{j}+\delta_{t}+\varepsilon_{j t}
\end{aligned}
$$

As before, the variable $\mathrm{Pay}_{\mathrm{jt}}$ refers to the compensation received by the $\mathrm{CEO}$ of firm $\mathrm{j}$ at

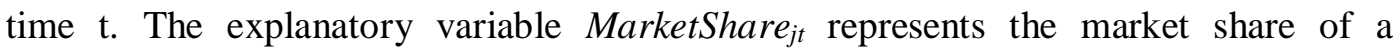
compensation consultant. The correct procedure to compute market share is to relate one firm with one consultant. This is because when firms use multiple consultants, it is not obvious which consultant has the greatest influence in determining CEO compensation. Therefore, we perform the analysis using those firms that employ only one compensation consultant. Market share is estimated as the number of client firms served divided by the total number of compensation consulting contracts in the market. ${ }^{8}$ To assess the robustness of empirical results, we also identify the two leading compensation consultants (on the basis of market share greater than 10\%) in the UK and estimate their isolated effects on CEO compensation. Similar to previous regression

\footnotetext{
${ }^{8}$ A better proxy to estimate market share could be to use the amount of fees received from the compensation consulting business. Unfortunately, this type of proprietary information is not publicly available in the UK. Instead, we assume that the fee is proportional to client firm's sales and create an alternate, albeit less precise, proxy variable by multiplying the initially estimated market share by sales.
} 
analysis, specification (2) also includes various firm, CEO and corporate governance characteristics as control variables.

\section{Data}

With the introduction of Directors' Remuneration Report Regulations in 2002, UK listed firms are required to disclose the name of entity that provides advice or service in the executive pay setting process. This information is hand-collected from company annual reports. The sample is made up of non-financial UK FTSE 350 firms covering the period 2003-2006. We find that all but six companies with the available data employ at least one compensation consultant during these years. Due to non-availability of annual reports, mergers and acquisitions, etc., the final sample comprises 175 companies. The criteria to select the final sample are summarized in Table 1 (Panel A).

(Insert Table 1 here)

The industry distribution of sample firms is shown in Table 1 (Panel B). Firms are classified into a number of industries according to the Primary Standard Industrial Classification Code obtained from the Financial Analysis Made Easy (FAME) database. Overall, the sample firms are spread over several industrial sectors. The largest number of companies (68 firms) belongs to the manufacturing sector, followed by transportation \& communication sector (20 firms) and wholesale \& retail trade sector (19 firms).

Detailed CEO compensation data are also hand-collected from the director remuneration report section of firms' annual reports. This hugely laborious process involves 
collection of information on almost all disclosed components of CEO compensation: salary, bonus, stock grants, option grants, pension and other benefits. The very detailed coverage of CEO compensation information over several years makes our study one of the most comprehensive studies on executive compensation. Data on CEO characteristics and governance variables are also hand-collected from annual reports, while those on firm characteristics are collected from the database Datastream.

The descriptive statistics of the variables are presented in Table 2. Firm level statistics are presented in Panel A while those on compensation consultants are presented in Panel B. There are 700 observations related to 175 companies covering the four-year period 2003-2006. The mean (median) CEO annual compensation is £1.94 million (£1.40 million). The average equity-based compensation (stock and option grants) is about $£ 0.73$ million, representing about $38 \%$ of total pay. When cash bonus and pensions are added with equity-based pay, the average CEO variable compensation increases to $£ 1.36$ million. This is about $70 \%$ of total compensation.

The average stock return for sample firms is $14 \%$ (median is $17 \%$ ). Sales, which is a measure of firm size, have an average (median) of $£ 4.4$ billion ( $£ 1.3$ billion). Firm risk is measured by the volatility of monthly stock returns. We find that the average volatility of stock returns during the four years is equal to $33 \%$ (median $32 \%$ ). Each firm in the sample employs at least one compensation consultant. We observe that, on average, there are two compensation consultants per firm. One firm used up to eight compensation consultants. Examining the board of directors, we find that the average firm has 10 board members. The median firm has equal number of executives and nonexecutives. The Board of the retail company Morrisons had no non-executive member 
in 2003. Every company has a remuneration committee and it has, on average, four members. ${ }^{9}$ The average CEO is 53 years old and has worked as CEO in the company for six years.

(Insert Table 2 here)

The frequency distribution of pay consultants used by sample firms is presented in Panel B. We observe that 311 (44.4\%) firm-years have one compensation consultant while the rest $389(55.6 \%)$ use multiple compensation consultants. Of those firms employing more than one pay consultant, we find that $29.0 \%, 16.1 \%, 7.6 \%$ and $2.9 \%$ of firms use two, three, four and more than four consultants, respectively. Our findings are similar to Conyon et al. (2009) who find that $28 \%$ of their sample firms use two compensation consultants and $16 \%$ use three or more consultants. Voulgaris et al. (2008) also find that one-third of FTSE 100 and one-quarter of FTSE 250 firms employ multiple compensation consultants. The use of multiple consultants has become a common practice in the UK. In a comparative analysis, Conyon et al. (2009) observe that most US firms use only one pay consultant.

We count the total number of compensation consultants used in the UK and find that the sample firms have 83 different compensation consultants. A similar pattern is documented by Murphy and Sandino (2010) who find 72 different consulting firms in the USA. While most firms use the same number of pay consultants each year, some firms also change their consultants from one year to another. We observe that an

\footnotetext{
${ }^{9}$ The remuneration committee of Morrisons consists of three executive members. Diageo had eight remco members in 2004 and 2006.
} 
increase in the number of consultants takes place in 93 firm-years, whereas a decline occurs in 82 cases.

Although a large number of compensation consultants provide services to client firms, the market is quite concentrated as only a few consultants dominate the industry. Panel B of Table 2 shows the six leading executive compensation consultants used in the UK. These are the consultants with more than five per cent market share. The most frequently used consultant is the New Bridge Street. It captures about $17.9 \%$ of the total pay consulting contracts, followed closely by its rival consultant, Towers Perrin (15.1\%). The rest are Mercer (7.6\% each), Monks (6.9\%), Watson Wyatt (6.4\%) and Deloitte $(6.4 \%) .{ }^{10}$ These six leading consultant firms take up about $60.3 \%$ of the total compensation consulting businesses in the UK. With the exception of Deloitte, similar big five consultants are identified in the UK by Conyon et al. (2009). According to Murphy and Sandino (2010), the big six consultants in the US include Towers Perrin, Mercer, Watson Wyatt and Deloitte, and capture more than two-thirds of the total pay consulting contracts offered in 2006. Cadman et al. (2010) also document a similar picture. The dominance of a few consulting firms is an indication of the fact that competition in the sector is quite intense. The Herfindahl index, calculated as the sum of the market shares squared, is 0.073 . It confirms a high degree of competition facing the pay consulting business.

\footnotetext{
${ }^{10}$ New Bridge Street joined with Hewitt in 2008 to form Hewitt New Bridge Street whereas Towers Perrin merged with Watson Wyatt in 2009 to form Towers Watson.
} 


\section{Empirical results}

In analyzing the relationship between multiple compensation consultants and CEO compensation, we first perform a simple bivariate analysis. The sample firms are categorized according to the number of compensation consultants used and then the average (median) pay is calculated for each category. The results are presented in Table 3 (Panel A).

For firms employing only one compensation consultant, the average CEO total compensation is $£ 1.658$ million (median $=£ 1.239$ million). When firms with two consultants are considered, we observe an increase, albeit statistically insignificant, in total pay $($ mean $=£ 1.779$ million, median $=\$ 1.391$ million $)$. The positive trend in CEO compensation with an increase in the number of pay consultants continues further. The median CEO total compensation increases to $£ 1.583$ million when firms use three consultants instead of two consultants. The change is statistically significant (z-statistic $=2.19)$. In case of firms using more than four consultants, the mean total pay significantly increases to $£ 4.071$ million ( $\mathrm{t}$-statistic $=1.80$ ) whereas the median CEO compensation significantly increases to $£ 3.615$ million $(\mathrm{z}$-statistic $=2.04)$. A similar trend is observed when we analyze the various components of total compensation (salary, equity-based and variable pay) separately.

(Insert Table 3 here)

In Panel B, we look at the year-to-year change in compensation consultants and the associated change in CEO compensation. For 350 firm-years, there is no increase or 
decrease in the total number of consultants firms used. We find that no significant change in annual compensation takes place when the total number of consultants used by a firm remains the same. We also find that when a firm adds an additional consultant (93 firm-years), the average (median) total compensation increases by $8.5 \%(4.4 \%)$. Both equity-based pay and variable pay show a significant increase too. On the other hand, when firms reduce the number of compensation consultants (82 firm-years), there is no statistically significant change in CEO compensation.

We also make an analysis of CEO pay associated with the two leading compensation consultants (these have market share of $10 \%$ or more). Panel $\mathrm{C}$ of Table 3 reports the findings. The consultant firm New Bridge Street is solely used in case of 98 firm-years, whereas Towers Perrin is employed as the sole consultant in case of 54 firm-years. Comparing CEO pay data, we find that the mean (median) variable and total compensation is significantly larger when Towers Perrin is the only consultant of the firm rather than New Bridge Street.

Regression analysis

In this section, we discuss the results of multivariate regression analysis used to examine the two research questions of the study. Before we perform the regressions, we estimate the correlation coefficients among key variables. Overall, the estimated correlations are relatively small. We check for the possibility of serious multicollinearity problem and find that it is negligible (the variance inflations factors in the regression estimations are much less than 10). 
Our first purpose is to examine if the level of annual compensation changes when firms employ multiple pay consultants. The natural logarithm of equity-based and total compensation of CEOs are used as the dependent variables. The main explanatory variable is the total number of compensation consultants used by a firm. ${ }^{11}$ We first run regressions using the natural logarithm of the total number of consultants and present the results in Table 4. As an alternate to this continuous variable, we use indicator variables that are equal to one for firms with two (three) or more consultants, and zero otherwise. $^{12}$

(Insert Table 4 here)

The results show that the use of multiple consultants is significantly related to equitybased compensation. The regression coefficients of the variable representing the number of compensation consultants are positive and statistically significant for both pooled regression (column 1) and the random effects regression (column 2). The results indicate that equity-based compensation increases as the number of pay consultants increases. When we perform the analysis with total compensation, the results of which are presented in columns (3) and (4), we observe that although the estimated coefficients of the consultant variable are positive, these are statistically insignificant. In unreported regressions, we also examine variable compensation and find similar result. On the basis of these findings, we conclude that the practice of employing multiple consultants is associated with significantly higher equity-based compensation. The

\footnotetext{
${ }^{11}$ The use of proportions of variable pay and equity pay mix as the dependent variable does not materially change our results. Examining whether CEO compensation is lower for firms without consultants is not meaningful here because we identify only six firms that do not have a consultant.

${ }^{12}$ Because these results are not different from those presented in the paper, we do not report them.
} 
finding suggests that firms decide to employ multiple consultants because different consultants specialize in different aspects of pay (Bender, 2008).

The above relationship between CEO compensation and the total number of compensation consultants employed by a firm is examined using a variety of control variables representing firm, corporate governance and CEO characteristics. Many of these variables exhibit statistically significant effects in the expected direction. For example, we find that variables like stock return (a measure of firm performance) and firm size positively affect CEO pay. These are indeed a stylized fact in the executive compensation literature (Cadman et al., 2010; Murphy and Sandino, 2010; Brick et al., 2006). ${ }^{13}$ We find that the coefficients of board size are significantly positive. The result suggests that firms with larger boards pay their CEOs more. The finding is consistent with the argument that a larger board is less effective and more susceptible to the influence of the CEO. We also observe that CEO duality has a significant influence on lowering executive compensation. This is not surprising because the incidence of CEO duality is common among founder-CEO managed firms in the UK. We find that the longer a CEO holds the position in a firm, the higher is the pay. The finding is consistent with the literature because $\mathrm{CEO}$ with a longer tenure is rewarded with higher pay for possessing more valuable human capital (Brick et al., 2006).

The analysis above involves estimations with the total number of compensation consultants employed by a firm. We next perform an analysis to examine whether CEO compensation is related to change in the number of pay consultants. We therefore split the sample into three categories of firms representing increase, decrease and no change

${ }^{13}$ Sales are commonly adopted in studies to proxy for firm size (Conyon et al., 2009; Murphy and Sandino, 2010). There is no change in the results when total assets is used as another proxy for firm size. 
in the number of pay consultants from one year to another. These different categories are estimated as individual dummy variables (dummy equals one if there in an increase, decrease, or no change in the number of consultants used, and zero otherwise). The estimated regression results are presented in Table 5.

(Insert Table 5 here)

We observe that an increase in the number of consultants leads to an increase in both CEO equity-based compensation (columns 1 and 2) and total compensation (columns 3 and 4). The estimated coefficients of the variable - increase in consultants - are positive and statistically significant. Interestingly, we also observe that when firms reduce the number of pay consultants, there is no corresponding reduction in CEO pay. In unreported regressions, we take the first differences of several explanatory variables and still obtain consistent findings. The results presented here complement the earlier findings reported in Table 4 showing that the use of multiple compensation consultants is associated with an increase in CEO pay. ${ }^{14}$

We now proceed to address the second research question, namely the empirical relation between the market shares of compensation consultants and the client firm's CEO pay. Table 6 reports the results. ${ }^{15}$ Pooled regression results examining equity-based

14 In a robustness analysis, we examine if an increase or decrease in the number of pay consultants is related to percentage change in annual compensation. These results are quite similar, and therefore, are not presented separately. We also examine if an arriving pay consultant relates to an increase in CEO pay. Focusing on firms employing one consultant, we observe that only 40 firm-years experience a change in pay consultant. Although the estimated regression coefficients of the change in consultant variable are positive, these are statistically insignificant, perhaps due to the small number of observations.

${ }^{15}$ As mentioned earlier, the market share of compensation consultant is calculated using firms with only one consultant. This procedure, on the one hand, allows to clearly identify the share of each consultant; on the other hand, it leads to a reduction in the number of firm-year observations (311). The regressions reported here include the statistically significant control variables only. 
compensation and total compensation are presented in columns (1) and (3). We observe that the regression coefficients of the market share variable are positive and statistically significant. To check the robustness of our results, we also employ random effects regressions and report the findings in columns (2) and (4). The core results remain unchanged. A statistically significant positive coefficient of market share is observed in case of equity-based compensation.

\section{(Insert Table 6 here)}

The results suggest that greater market share of compensation consultants is associated with higher client firm's CEO pay. The rent extraction view indicates that pay consultants have a strong incentive to serve the interest of CEOs in order to retain their pay consulting business with client firms. The likelihood of losing business with the client firm is greater if the compensation consultant does not act in favor of the CEO. It is thus sensible for the consultant to advise towards higher CEO pay in order to maintain or even increase its market share. The argument is supported by Bebchuk and Fried (2003) who assert the following: "Providing advice that hurts the CEO's pocketbook is hardly a way to enhance the consultant's chances of being hired in the future by this firm or, indeed, by any other firms".

We perform an additional analysis whereby the effects of two leading compensation consultants are isolated. ${ }^{16}$ Dummy variables are used to identify each consultant. As before, firm, corporate governance and CEO-specific control variables are included.

\footnotetext{
${ }^{16}$ We restrict to two pay consultants because the market shares of other consultants are below $10 \%$ and these are used by a smaller number of firms.
} 
The results are presented in Table 7. Columns (1) and (4) show results for New Bridge Street while columns (2) and (5) for Towers Perrin. We also estimate regressions using specifications that include both consultants jointly (columns 3 and 6).

(Insert Table 7 here)

The overall finding from Table 7 is that CEO compensation is significantly higher when the client firm receives advice from New Bridge Street and Towers Perrin. The estimated consultant dummy coefficients are positive with only two coefficients being statistically insignificant. If compensation consultants compete by way of advising towards greater pay for the client firm's CEO, it is unsurprising to observe this tendency of leading consultants being associated with greater CEO pay. ${ }^{17}$ Anecdotal evidence also provides support to our finding: “...there is a clear link between companies with controversial remuneration practices and their pay consultants...A recent survey found that, together with its larger US rival Towers Perrin, New Bridge had effectively cornered the market..." 18

One may argue that larger firms that normally pay their CEOs more tend to employ compensation consultants with greater market share. We therefore examine the choice of the two leading compensation consultants (i.e. Towers Perrin and New Bridge Street) using logistic regression approach. The results show that firms paying their CEOs more tend to employ Towers Perrin and New Bridge Street, but there is no statistical support

\footnotetext{
${ }^{17}$ The model specifications used here implicitly assume that both New Bridge Street and Towers Perrin get employed by firms with similar firm characteristics.

${ }^{18}$ The Mail (February 6, 2005): 'Get me an above-average pay consultant'.
} 
for the conjecture that larger firms mostly receive recommendations from these two leading consultants.

\section{Additional sensitivity analysis}

The empirical findings presented so far on the association of CEO pay with compensation consultants and their market shares may be subject to the endogeneity problem. The number of compensation consultants can be an endogenous choice variable that most likely depends on factors like firm size, firm risk, remuneration committee members, etc. Similarly, the market share of compensation consultants and CEO pay can be simultaneously determined. The consequence is that the results reported so far can be subject to bias. Prior studies commonly use the two-stage least squares (2SLS) regression method to tackle the endogeneity issue (e.g. Sun et al., 2009). Therefore, we perform a new analysis using the number of compensation consultants and their market share as endogenous variables and estimate the following two-equation system:

$$
\begin{aligned}
& \text { End.Var. }_{\cdot j t} \\
& =\alpha+\sum_{1}^{m} \beta_{m} I V_{j t}+\sum_{m}^{n} \beta_{n} \text { Controls__}_{j t}+\lambda_{j}+\delta_{t}+\varepsilon_{j t} \\
& \text { Pay }_{j t}=\alpha+\beta_{1} \text { End.Var }_{\cdot j t}+\sum_{2}^{n} \beta_{n} \text { Controls }_{-} B_{j t}+\lambda_{j}+\delta_{t}+\varepsilon_{j t}
\end{aligned}
$$

At first, we consider the number of compensation consultants as an endogenous choice variable and explain it by using factors like firm size, firm risk, size of the remuneration committee and CEO characteristics like age and tenure. The fitted values of the consultant variable are then used to explain CEO compensation. Two variables: the size 
of the remuneration committee and firm risk are used as instrumental variables. ${ }^{19}$ The CEO compensation regression includes other control variables like stock return, board size and CEO duality. As before, we analyze both equity-based compensation and total compensation.

The estimation results are presented in Table 8 (columns $1-3$ ). The first column explains the firm's choice of number of consultants. The regression result shows that larger and more risky firms are the ones which employ multiple consultants. Firms with larger remuneration committees also seek advice from higher number of pay consultants. On the other hand, firms with higher institutional share ownership and higher tenure of CEOs tend to have lesser number of compensation consultants. Columns (2) and (3) present the second-stage results of equity and total compensation. We observe that the coefficient of compensation consultant variable is positive and statistically significant. While the pooled and random effects regressions presented in Table 4 (Panel A) show statistically significant results for equity-based compensation and insignificant results for total compensation, the 2SLS results presented here show that the multiple consultant variable is significantly related to both measures of CEO compensation. These new results reinforce our conclusion that CEO pay increases with an increase in the total number of compensation consultants used by firms.

\section{(Insert Table 8 here)}

In the second part of the analysis, we examine if CEO compensation is related to market share of consultants. The first-stage regression considers market share as the

${ }^{19}$ The OLS results presented earlier in Tables 4-7 indicate that these two variables are not significantly related to CEO compensation. 
endogenous variable; the predicted values are then used in the second-stage to explain CEO pay. The size of remuneration committee and firm risk are used as instrumental variables. Columns (4) to (6) of Table 8 exhibit the results. We find that market share is significant positively related to equity-based compensation and total compensation of CEOs. The 2SLS results are consistent with those obtained earlier (in Table 6) from pooled and random effects regressions.

The positive relationship between CEO pay and the number of compensation consultants or their market shares could be driven by the firm's compensation contract itself. Firms with higher CEO pay contract may need to hire more compensation consultants and high reputation consultants (i.e., those with large market shares) for higher CEO pay justification. Therefore, we perform a robustness check by including lagged CEO pay in the first-stage regressions. Although the lagged analysis reduces the number of observations (and statistical significance), the main finding remains qualitatively similar.

\section{Summary and conclusions}

Compensation consultants are central to the CEO pay setting process but their role is currently understudied worldwide. Conyon et al. (2009) and Cadman et al. (2010) proclaim that little scientific evidence exists about the influence of compensation consultant on executive pay. Two opposing views on the role of compensation consultants are presented both in the media as well as in the academic literature (e.g. Bebchuk and Fried, 2003; Armstrong et al. 2008). On the one hand, compensation consultants are regarded as professional experts. They help firms to achieve optimal 
contracting by offering a valuable service without which executive compensation can not be appropriately designed. On the other hand, the rent extraction or managerial power perspective asserts that compensation consultants do not act independent of the influence of firm's executives. Consultants have strong incentives to advocate higher CEO compensation in order to enhance their chance of being hired in the future by the client firm for both pay and non-pay related services. Critics thus argue that by providing favorable advice, pay consultants are ratcheting up executive pay.

Recent availability of data on compensation consultants has created a growing interest among academics to investigate the influence of compensation consultants on CEO pay (Murphy and Sandino, 2010). A few studies show that CEOs of firms that use compensation consultants receive higher pay relative to those who do not employ a consultant (Cadman et al., 2010; Conyon et al., 2009; Armstrong et al., 2008; Voulgaris et al., 2008). The interesting issue that has not yet been examined is whether CEO compensation further increases or even declines when firms adopt not just one but multiple compensation consultants. Conyon et al. (2009) report that most US firms use only one compensation consultant. Therefore, an original hand-collected dataset of UK firms for the period 2003-2006 is employed in this study.

We find that almost all UK firms in our sample seek recommendations from compensation consultants, and the majority of the sample firms use multiple pay consultants. A bivariate analysis reveals that CEO pay increases as the number of pay consultants employed by the firm increases. Statistical analysis controlling for firm, CEO and corporate governance characteristics shows that the use of multiple compensation consultants is positively related to CEO equity-based pay. In addition, we 
find that an increase in the number of consultants is associated with an increase in CEO pay, but there is no reduction in pay when the total number of pay consultants declines. The evidence lends support to the conjecture that firms employ multiple consultants to provide a justification of increased level of executive compensation.

Critics argue that compensation consultants usually advise in favor of higher CEO pay in order to maintain their business interests with client firms and survive from intense competition. We examine this issue and observe that the market share of compensation consultants is positively related to CEO pay. This is particularly true for consultants with the two largest market shares (i.e. New Bridge Street and Towers Perrin). The finding is consistent with the argument that pay consultants act to survive competition from other consultants. Further analysis shows that firms that pay higher compensation to CEOs (but not necessarily larger firms) tend to choose consultants with the two largest market shares.

Overall, the results of the study pose doubts on the claim that the use of compensation consultants in the executive pay setting process promotes optimal contracting. Rather the evidence is consistent with the managerial power view whereby the client firm's CEO receives higher pay recommendations from compensation consultants. Our findings indicate a need to closely monitor the functioning of compensation consultants if shareholders' interest is to be served. We suggest that future research examines the role of compensation consultants using data from other countries and explores in detail the institutional mechanisms that can be deployed to govern the practice of employing compensation consultants. Our finding that UK CEOs receive higher pay from 
employing multiple pay consultants raises the question why CEOs of US firms do not use a similar practice. This is also an interesting issue for future research. 


\section{References}

Anderson, R., Bizjak, J., 2003. An empirical examination of the role of the CEO and the compensation committee in structuring executive pay. Journal of Banking and Finance $27,1323-1348$

Armstrong, C., Ittner, C., Larcker, D., 2008. Economic characteristics, corporate governance, and the influence of compensation consultants on executive pay levels. SSRN Working Paper No. 1145548.

Bebchuk, L., Fried, J., 2003. Executive compensation as an agency problem. Journal of Economic Perspectives 17, 71-92.

Bender, R., 2008. Paying for advice: the role of remuneration consultant in the UK listed companies', Working Paper, Cranfield University.

Bizjak, J., Lemmon, M., Naveen, L., 2008. Does the use of peer groups contribute to higher pay and less efficient compensation? Journal of Financial Economics 90, 152168.

Brick, I., Palmon, O., Wald, J., 2006. CEO compensation, director compensation and firm performance: evidence of cronyism? Journal of Corporate Finance 12, 403-23.

Cadman, B., Carter, M., Hillegeist, S., 2010. The incentives of compensation consultants and CEO pay. Journal of Accounting and Economics 49, 263-280.

Conyon, M., Peck, S., Sadler, G., 2009. Compensation consultants and executive pay: Evidence from the United States and the United Kingdom. Academy of Management Perspectives 23, 43-55.

Crystal, G., 1991. Why CEO compensation is so high? California Management Review 34, 9-29.

Murphy, K., Sandino, T., 2010. Executive pay and "independent" compensation consultants. Journal of Accounting and Economics 49, 247-262.

Sun, J., Cahan, S., Emanuel, D., 2009. Compensation committee governance quality, chief executive officer stock option grants, and future firm performance. Journal of Banking and Finance 33, 1507-1519.

Voulgaris, G., Stathopoulos, K., Walker, M., 2008. Compensation consultants and executive pay: UK evidence. SSRN Working Paper No. 1293864. 


\section{Appendix. Variable definitions}

\section{Variable Name}

CEO compensation

Total compensation

Equity-based compensation

Variable compensation

Compensation consultants

Consultants

Market share

\section{Firm characteristics}

Stock return

Firm size

Firm risk

Governance characteristics

Board size

Non-executives

RemCo

Instit. own.

CEO duality

CEO characteristics

Age

Tenure

\section{Definitions}

The sum of salary, bonus, benefit, defined-benefit pension increment, the value of restricted stock grant and stock option grant. The sum of the value of restricted stock grants and stock option grants.

The sum of bonus, pension increment, the values of restricted stock grants and stock option grants.

The natural logarithm of the number of compensation consultants.

The number of compensation consulting contracts a consulting firm has secured divided by the total number of compensation consulting contracts in the market.

The natural logarithm of annual change of a firm's return index.

The natural logarithm of sales.

The standard deviation of annualised monthly stock return over prior 120-months.

The natural logarithm of total number of directors on the board.

The number of non-executive directors divided by the number of executive directors.

The natural logarithm of total number of remuneration committee members.

The percentage of total institutional ownership that is greater than three per cent.

A dummy variable that equals one if the CEO is also the chair of the Board, zero otherwise.

The natural logarithm of CEO age.

The natural logarithm of the number of years the CEO has held the position of CEO at the firm. 


\section{Table 1. Selection of sample companies}

The sample is made up of 175 non-financial UK firms during 2003-2006. Firms are classified into different industries using the UK Primary Standard Industrial Classification Codes collected from the Financial Analysis Made Easy database.

\section{Panel A. Sample selection}

Number of non-financial FTSE350 firms

Firms with data unavailable, at least in one year, due to:

- takeover/delisted

- annual report not available

- compensation not disclosed

Firms without compensation consultant

Total number of sample firms

\section{Panel B. Industry classification}

$\begin{array}{lcc}\text { Industry } & \text { Number of firms } & \text { Percentage } \\ \text { Mining } & 10 & 6 \% \\ \text { Manufacturing } & 68 & 39 \% \\ \text { Construction } & 16 & 9 \% \\ \text { Wholesale and Retail } & 19 & 11 \% \\ \text { Transportation and Communication } & 20 & 11 \% \\ \text { Utilities } & 9 & 5 \% \\ \text { Other } & \underline{33} & \underline{19 \%} \\ \text { Total } & 175 & 100 \%\end{array}$




\section{Table 2. Descriptive statistics}

\section{Panel A: Firm-level statistics}

The table reports the descriptive statistics for the sample of 175 non-financial UK firms during 2003-2006 (700 firm-years). All variables are defined in the Appendix.

\begin{tabular}{|c|c|c|c|c|c|}
\hline & Mean & Median & Min. & Max. & St. dev. \\
\hline Total compensation (£m) & 1.94 & 1.40 & 0.15 & 22.79 & 1.85 \\
\hline Equity-based compensation ( $£$ m) & 0.73 & 0.37 & 0.00 & 20.37 & 1.31 \\
\hline Variable compensation (£m) & 1.36 & 0.89 & 0.00 & 21.93 & 1.69 \\
\hline Stock return & 0.14 & 0.17 & -2.29 & 1.03 & 0.29 \\
\hline Sales (£mil) & 4,405 & 1,331 & 20 & 155,000 & 11,900 \\
\hline Firm risk & 0.33 & 0.32 & 0.01 & 0.94 & 0.12 \\
\hline No. of compensation consultants & 2 & 2 & 1 & 8 & 1 \\
\hline No. of board members & 10 & 10 & 5 & 21 & 2 \\
\hline Non-executives/executives ratio & 2 & 1 & 0 & 8 & 1 \\
\hline No. of RemCo members & 4 & 4 & 2 & 8 & 1 \\
\hline Institutional ownership & 0.27 & 0.21 & 0.00 & 0.74 & 0.14 \\
\hline CEO age (years) & 53 & 54 & 31 & 69 & 6 \\
\hline CEO tenure (years) & 6 & 4 & 1 & 34 & 6 \\
\hline
\end{tabular}




\section{Panel B: Compensation consultant statistics}

The table reports the frequency distribution of compensation consultants used by sample firms.

Number of consultants

$\begin{array}{lllll}2003 & 2004 & 2005 & 2006 & \begin{array}{l}\text { Total } \\ \text { firm- } \\ \text { years }\end{array}\end{array}$

\begin{tabular}{ccccccc}
1 & 82 & 76 & 76 & 77 & 311 & 44.4 \\
2 & 50 & 53 & 49 & 51 & 203 & 29.0 \\
3 & 28 & 25 & 31 & 29 & 113 & 16.1 \\
4 & 11 & 13 & 17 & 12 & 53 & 7.6 \\
5 or more & 4 & 8 & 2 & 6 & 20 & 2.9 \\
\hline Total & 175 & 175 & 175 & 175 & 700 & 100.0
\end{tabular}

Name of the consultant

\begin{tabular}{|c|c|c|c|c|c|c|}
\hline New Bridge Street & 55 & 64 & 60 & 68 & 247 & 17.9 \\
\hline Towers Perrin & 57 & 54 & 51 & 46 & 208 & 15.1 \\
\hline Mercer & 28 & 28 & 26 & 23 & 105 & 7.6 \\
\hline Monks & 30 & 26 & 19 & 20 & 95 & 6.9 \\
\hline Deloitte & 20 & 23 & 23 & 23 & 89 & 6.4 \\
\hline Watson Wyatt & 23 & 21 & 22 & 23 & 89 & 6.4 \\
\hline Others & 120 & 140 & 146 & 143 & 549 & 39.7 \\
\hline Total & 333 & 356 & 347 & 346 & 1382 & 100.0 \\
\hline
\end{tabular}




\section{Table 3. Compensation consultants and CEO pay}

The table reports mean, median and standard deviation of CEO compensation. Panel A presents compensation for firms categorized according to the number of consultants used. Panel B presents percentage change in compensation. Panel C presents compensation for firms with the two largest consultants (with $10 \%$ or more market share). The sample consists of 175 non-financial UK firms during 2003-06. The asterisks $* * *$, ** and * show statistical significance at the $0.01,0.05$ and 0.10 level, respectively.

Panel A: Number of consultants and CEO compensation (£000)

$\begin{array}{cccc}\text { Salary } & \begin{array}{c}\text { Equity-based } \\ \text { compensation }\end{array} & \begin{array}{c}\text { Variable } \\ \text { Compensation }\end{array} & \begin{array}{c}\text { Total } \\ \text { Compensation }\end{array}\end{array}$

One consultant $(\mathrm{N}=311)$

Mean

Median

St. dev.

Mean

Median

St. dev.

Mean

Median

St. dev.

Mean

Median

St. dev.

Mean

Median

St. dev.

488
440

$$
544
$$

313

751

1658

190

796

1145

1314

Two consultants (N=203)

$521^{* *}$

$468^{* *}$

207

$$
624
$$

1199

1779

396

879

1391

959

1258

1461

Three consultants $(\mathrm{N}=113)$

538
503
182

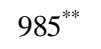

$1675^{* *}$

$2274^{*}$

$524^{* *}$

$999^{* * *}$

$1583^{* *}$

2159

2421

2513

Four consultants $(\mathrm{N}=53)$

$\begin{array}{cccc}595^{*} & 1221 & 2026 & 2673 \\ 558 & 594 & 1454 & 2046 \\ 252 & 1857 & 2552 & 2752\end{array}$

More than four consultants $(\mathrm{N}=20)$

$741^{\text {*** }}$

$773^{\text {*** }}$

1811

3222

$4071^{*}$

1107

2563

$3615^{* * *}$

238

1868

2940

3020 
Panel B: Changes in the number of consultants and CEO compensation

\begin{tabular}{|c|c|c|c|c|}
\hline & $\begin{array}{c}\text { Change in } \\
\text { Salary }\end{array}$ & $\begin{array}{c}\text { Change in } \\
\text { Equity-based } \\
\text { Compensation }\end{array}$ & $\begin{array}{c}\text { Change in } \\
\text { Variable } \\
\text { Compensation }\end{array}$ & $\begin{array}{c}\text { Change in } \\
\text { Total } \\
\text { Compensati }\end{array}$ \\
\hline \multicolumn{5}{|c|}{ No change in the number of consultants used $(\mathrm{N}=350)$} \\
\hline Mean & 0.003 & 0.002 & 0.006 & 0.007 \\
\hline Median & 0.004 & 0.001 & 0.005 & 0.016 \\
\hline St. dev. & 0.012 & 0.123 & 0.135 & 0.152 \\
\hline \multicolumn{5}{|c|}{ Increase in the number of consultants used $(\mathrm{N}=93)$} \\
\hline Mean & 0.005 & $0.065^{* * *}$ & $0.075^{* * *}$ & $0.085^{* * *}$ \\
\hline Median & $0.005^{*}$ & $0.011^{* * *}$ & $0.024^{* * *}$ & $0.044^{* * *}$ \\
\hline St. dev. & 0.009 & 0.304 & 0.310 & 0.320 \\
\hline \multicolumn{5}{|c|}{$\underline{\text { Decrease in the number of consultants used }(\mathrm{N}=82)}$} \\
\hline Mean & 0.005 & -0.009 & -0.002 & 0.008 \\
\hline Median & 0.004 & 0.008 & 0.013 & 0.025 \\
\hline St. dev. & 0.008 & 0.344 & 0.344 & 0.346 \\
\hline
\end{tabular}

Panel C: The two largest consultants and CEO compensation (£000)

$\begin{array}{cccc}\text { Salary } & \begin{array}{c}\text { Equity-based } \\ \text { compensation }\end{array} & \begin{array}{c}\text { Variable } \\ \text { Compensation }\end{array} & \begin{array}{c}\text { Total } \\ \text { Compensation }\end{array}\end{array}$

$\underline{\text { New Bridge Street }(\mathrm{N}=98)}$

$\begin{array}{lcccc}\text { Mean } & 438 & 520 & 799 & 1499 \\ \text { Median } & 412 & 349 & 592 & 1260 \\ \text { St. dev. } & 146 & 706 & 867 & 1088 \\ & & \text { Towers Perrin }(\mathrm{N}=54) & \\ \text { Mean } & 658^{* * *} & 953 & 1435^{* * *} & 2733^{* * * *} \\ \text { Median } & 646^{* * *} & 757^{* * *} & 1175^{* *} & 2201^{* * *} \\ \text { St. dev. } & 260 & 1141 & 1436 & 1830\end{array}$




\section{Table 4. The number of compensation consultants and CEO pay}

The table presents the results for pooled and random effects regressions. The sample consists of 175 non-financial firms during 2003-06 (700 firm-years). The dependent variables are CEO equity-based compensation and total compensation, expressed in the natural logarithm of their values. All variables are defined in the Appendix. The p-values are reported in parentheses. The asterisks $* * *, * *$ and $*$ show statistical significance at the $0.01,0.05$ and 0.10 level, respectively.

\begin{tabular}{|c|c|c|c|c|c|}
\hline \multirow[b]{2}{*}{ Variable } & \multicolumn{2}{|c|}{ Equity-based compensation } & \multicolumn{3}{|c|}{ Total compensation } \\
\hline & $\begin{array}{l}\text { Pooled } \\
\text { regression }\end{array}$ & $\begin{array}{r}\text { Random } \\
\text { effects } \\
\text { regression } \\
(2)\end{array}$ & $\begin{array}{r}\text { Pooled } \\
\text { regression } \\
\text { (3) }\end{array}$ & $\begin{array}{r}\text { Random } \\
\text { effects } \\
\text { regression } \\
(4)\end{array}$ & \\
\hline \multirow[t]{2}{*}{ Intercept } & $-2.010^{*}$ & -1.363 & $2.531 * * *$ & 2.693 & $* * *$ \\
\hline & $(0.071)$ & $(0.352)$ & $(0.000)$ & $(0.000)$ & \\
\hline \multirow[t]{2}{*}{ Consultants } & $0.303^{*}$ & $0.342 *$ & 0.051 & 0.043 & \\
\hline & $(0.083)$ & $(0.072)$ & $(0.416$ & $(0.538)$ & \\
\hline \multirow[t]{2}{*}{ Stock return } & $0.944 * * *$ & $0.838 * * *$ & $0.281 * * *$ & 0.249 & $* * *$ \\
\hline & $(0.001)$ & $(0.002)$ & $(0.001)$ & $(0.001)$ & \\
\hline \multirow[t]{2}{*}{ Firm size } & $0.155^{*}$ & $0.178^{*}$ & $0.186 * * *$ & 0.181 & $* * *$ \\
\hline & $(0.060)$ & $(0.078)$ & $(0.000)$ & $(0.000)$ & \\
\hline \multirow[t]{2}{*}{ Board size } & $2.331 * * *$ & $1.870^{* * * *}$ & $0.801 * * *$ & 0.776 & $* * *$ \\
\hline & $(0.000)$ & $(0.001)$ & $(0.000)$ & $(0.000)$ & \\
\hline \multirow[t]{2}{*}{ Non-executives } & -0.107 & -0.131 & $0.072 * * *$ & 0.029 & \\
\hline & $(0.404)$ & $(0.0389)$ & $(0.005)$ & $(0.315)$ & \\
\hline \multirow[t]{2}{*}{ Institutional ownership } & -0.011 & -0.005 & $-0.014 * * *$ & -0.009 & $*$ \\
\hline & $(0.048)$ & $(0.606)$ & $(0.001)$ & $(0.059)$ & \\
\hline \multirow[t]{2}{*}{ CEO duality } & $-1.189 * * *$ & $-0.989 * *$ & $-0.494 * * *$ & -0.451 & $* * *$ \\
\hline & $(0.003)$ & $(0.050)$ & $(0.000)$ & $(0.000)$ & \\
\hline \multirow[t]{2}{*}{ CEO tenure } & 0.15 & $0.279 * * *$ & $0.093 * * *$ & 0.098 & $* * *$ \\
\hline & $(0.115)$ & (0.006) & $(0.000)$ & $(0.001)$ & \\
\hline
\end{tabular}

Adj. R ${ }^{2}$

0.11

0.14

0.31

0.44 


\section{Table 5. Changes in compensation consultants and CEO pay}

The table presents the results for pooled and random effects regressions. The sample consists of 175 non-financial firms during 2003-06. Calculating year-to-year change in compensation consultant results in 525 firm-year observations. The dependent variables are CEO equity-based compensation and total compensation, expressed in the natural logarithm of their values. All variables are defined in the Appendix. The p-values are reported in parentheses. The asterisks $* * *, * *$ and $*$ show statistical significance at the $0.01,0.05$ and 0.10 level, respectively.

\begin{tabular}{|c|c|c|c|c|}
\hline \multirow[b]{2}{*}{ Variable } & \multicolumn{2}{|c|}{$\begin{array}{l}\text { Equity-based } \\
\text { compensation }\end{array}$} & \multicolumn{2}{|c|}{$\begin{array}{c}\text { Total } \\
\text { compensation }\end{array}$} \\
\hline & $\begin{array}{l}\text { Pooled } \\
\text { regression } \\
\text { (1) }\end{array}$ & $\begin{array}{l}\text { Random } \\
\text { effects } \\
\text { regression } \\
\quad(2)\end{array}$ & $\begin{array}{l}\text { Pooled } \\
\text { regression } \\
\text { (3) }\end{array}$ & $\begin{array}{l}\text { Random } \\
\text { effects } \\
\text { regression } \\
\text { (4) }\end{array}$ \\
\hline Intercept & $\begin{array}{r}-0.152 \\
(0.540)\end{array}$ & $\begin{array}{r}0.170 \\
(0.414)\end{array}$ & $\begin{array}{r}0.209 \\
(0.408)\end{array}$ & $\begin{array}{r}0.239 \\
(0.266)\end{array}$ \\
\hline Increase in consultants & $\begin{array}{c}0.053^{*} \\
(0.104)\end{array}$ & $\begin{array}{l}0.058 * * \\
(0.039)\end{array}$ & $\begin{array}{l}0.066^{* *} \\
(0.053)\end{array}$ & $\begin{array}{l}0.069^{* * * *} \\
(0.021)\end{array}$ \\
\hline Decrease in consultants & $\begin{array}{r}-0.012 \\
(0.741)\end{array}$ & $\begin{array}{r}-0.013 \\
(0.704)\end{array}$ & $\begin{array}{r}-0.002 \\
(0.960)\end{array}$ & $\begin{array}{l}-0.005 \\
(0.895)\end{array}$ \\
\hline Lag compensation & $\begin{array}{l}-0.079 * * * \\
(0.008)\end{array}$ & $\begin{array}{l}-0.078 * * * \\
(0.008)\end{array}$ & $\begin{array}{l}-0.110^{* * *} \\
(0.000)\end{array}$ & $\begin{array}{l}-0.109^{* * *} \\
(0.000)\end{array}$ \\
\hline Stock return & $\begin{array}{l}0.085 * * \\
(0.036)\end{array}$ & $\begin{array}{l}0.180 * * \\
(0.055)\end{array}$ & $\begin{array}{l}0.112^{* * * *} \\
(0.014)\end{array}$ & $\begin{array}{l}0.102 * * \\
(0.028)\end{array}$ \\
\hline Firm size & $\begin{array}{l}0.019 * * \\
(0.016)\end{array}$ & $\begin{array}{l}0.019 * * * \\
(0.010)\end{array}$ & $\begin{array}{l}0.027 * * * \\
(0.001)\end{array}$ & $\begin{array}{l}0.025^{* * *} \\
(0.001)\end{array}$ \\
\hline Board size & $\begin{array}{r}0.047 \\
(0.223)\end{array}$ & $\begin{array}{r}0.047 \\
(0.261)\end{array}$ & $\begin{array}{c}0.073^{*} \\
(0.076)\end{array}$ & $\begin{array}{c}0.078^{*} \\
(0.082)\end{array}$ \\
\hline Non-executives & $\begin{array}{l}-0.001 \\
(0.973)\end{array}$ & $\begin{array}{r}0.001 \\
(0.921)\end{array}$ & $\begin{array}{r}-0.003 \\
(0.802)\end{array}$ & $\begin{array}{l}-0.001 \\
(0.904)\end{array}$ \\
\hline Institutional ownership & $\begin{array}{r}-0.001 \\
(0.217)\end{array}$ & $\begin{array}{l}-0.002 * \\
(0.088)\end{array}$ & $\begin{array}{r}-0.001 \\
(0.328)\end{array}$ & $\begin{array}{r}-0.001 \\
(0.229)\end{array}$ \\
\hline CEO duality & $\begin{array}{l}-0.060 * * * \\
(0.009)\end{array}$ & $\begin{array}{l}-0.062 * * * \\
(0.010)\end{array}$ & $\begin{array}{l}-0.084 * * * \\
(0.001)\end{array}$ & $\begin{array}{l}-0.089^{* * * *} \\
(0.001)\end{array}$ \\
\hline CEO tenure & $\begin{array}{r}0.001 \\
(0.709)\end{array}$ & $\begin{array}{r}0.001 \\
(0.731)\end{array}$ & $\begin{array}{r}0.003 \\
(0.251)\end{array}$ & $\begin{array}{r}0.003 \\
(0.265)\end{array}$ \\
\hline Adj. $\mathrm{R}^{2}$ & 0.05 & 0.05 & 0.09 & 0.09 \\
\hline
\end{tabular}


Table 6. Market share of compensation consultants and CEO pay

The table presents the results for pooled and random effects regressions. The market share of a consultant is estimated by considering firms with only one consultant (311 firm-year observations). The sample period is 2003-06. All variables are defined in the Appendix. The p-values are in parentheses. The asterisks $* * *, * *$ and $*$ show statistical significance at the $0.01,0.05$ and 0.10 level, respectively.

\begin{tabular}{|c|c|c|c|c|}
\hline \multirow{2}{*}{ Variable } & \multicolumn{2}{|c|}{ Equity-based compensation } & \multicolumn{2}{|c|}{ Total compensation } \\
\hline & $\begin{array}{l}\text { Pooled } \\
\text { regression } \\
\text { (1) }\end{array}$ & $\begin{array}{l}\text { Random } \\
\text { effects } \\
\text { regression } \\
(2)\end{array}$ & $\begin{array}{l}\text { Pooled } \\
\text { regression } \\
\text { (3) }\end{array}$ & $\begin{array}{l}\text { Random } \\
\text { effects } \\
\text { regression } \\
\text { (4) }\end{array}$ \\
\hline \multirow[t]{2}{*}{ Intercept } & $4.766 * * *$ & $4.670 * * *$ & $6.945 * * *$ & $6.987 * * *$ \\
\hline & $(0.000)$ & $(0.000)$ & $(0.000)$ & $(0.000)$ \\
\hline \multirow[t]{2}{*}{ Market share } & $0.216^{* * *}$ & $0.139 *$ & $0.065 * * *$ & 0.021 \\
\hline & $(0.001)$ & $(0.075)$ & $(0.000)$ & $(0.199)$ \\
\hline \multirow[t]{2}{*}{ Non-executives } & $0.477 * *$ & $0.432 * *$ & $0.173 * * *$ & $0.102 *$ \\
\hline & $(0.013)$ & $(0.034)$ & $(0.000)$ & $(0.051)$ \\
\hline \multirow[t]{2}{*}{ Institutional ownership } & 0.032 & 0.004 & 0.003 & $-0.009 * *$ \\
\hline & $(0.152)$ & $(0.804)$ & $(0.747)$ & $(0.039)$ \\
\hline \multirow[t]{2}{*}{ CEO duality } & $-1.413^{* *}$ & $-1.430 * *$ & -0.249 & -0.116 \\
\hline & $(0.019)$ & $(0.047)$ & $(0.181)$ & 0.538 \\
\hline Adj. $R^{2}$ & 0.09 & 0.07 & 0.14 & 0.11 \\
\hline
\end{tabular}




\section{Table 7. The two largest compensation consultants and CEO pay}

The table presents the results for pooled regressions. The sample includes firms with only one consultant (311 firm-year observations). The two largest consultants (New Bridge Street and Towers Perrin) are identified based on their market shares and expressed as dummy variables. The sample period is 2003-06. All variables are defined in the Appendix. The p-values are in parentheses. The asterisks $* * *, * *$ and $*$ show statistical significance at the $0.01,0.05$ and 0.10 level, respectively.

Equity-based compensation

Variable

Intercept

New Bridge Street

Towers Perrin

Firm size

Board size

Board size

Non-executives

Institutional ownership

CEO duality

CEO tenure

Adj. $R^{2}$
(1)

(2)

$-2.028$

(0.248)

$0.545^{*}$

(0.074)

(2)

$$
-1.172
$$

(0.508)

$-1.558$

(0.376)

0.703 **

(0.025)

0.575

(0.179)

$0.808^{* *}$

0.062

(0.069)

$$
0.101
$$

(0.594)

(0.376)

$2.445 * * *$

$2.248 * * *$

(0.000)

(0.002)

$0.376^{*}$

0.360 *

(0.062)

(0.078)

$-0.004$

(0.603)

$-1.115^{*}$

(0.860)

(0.049)

$-1.179$

-0.360 ***

(0.037)

(0.008)

$-0.389 * *$

(0.004)

0.14

0.14
$0.072 * * *$

(0.533)

$2.194 * * *$

(0.002)

$0.395 * *$

(0.047)

0.004

(0.867)

$-1.123^{* *}$

(0.037)

$-0.345^{* * *}$

(0.011)

0.15
Total compensation

(4)

(5)

(6)

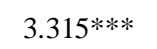

$3.669 * * * \quad 3.592 * * *$

(0.000)

(0.000)

(0.000)

0.048

$0.141 *$

(0.514)

(0.052)

$0.429^{* * *} \quad 0.476 * * *$

(0.000) (0.000)

$0.119^{* * *}$

$0.100^{* * * *}$

$0.102 * * *$

(0.000)

(0.000)

$(0.000)$

$0.857 * * *$

$0.719 * * *$

0.709 ***

(0.000)

(0.000)

(0.000)

$0.109 * * *$

$0.114 * * *$

0.121 ***

(0.000)

(0.000)

(0.000)

$-0.013^{*}$

$-0.006$

$-0.004$

(0.065)

(0.379)

(0.538)

$-0.263^{*}$

$-0.279 * *$

$-0.268 * *$

(0.088)

(0.049)

(0.049)

$0.084^{* * * *}$

$0.084^{* * *}$

$0.093 * * *$

(0.004)

(0.004)

(0.001)

0.32

0.37

0.38 


\section{Table 8: 2SLS estimates of multiple consultants and consultant market share}

The table presents the results for the two-stage least squares (2SLS) regressions. The OLS columns represent the results of the first stage regression. The sample period is 2003-06 (700 firm-year observations for Columns 1 - 3 and 311 firm-year observations for Columns 4 -6). All variables are defined in the Appendix. The p-values are in parentheses. The asterisks $* * * * *$ and $*$ show statistical significance at the $0.01,0.05$ and 0.10 level, respectively.

\begin{tabular}{|c|c|c|c|c|c|c|}
\hline \multirow{4}{*}{ Variable } & \multicolumn{3}{|c|}{ Multiple compensation consultants } & \multicolumn{3}{|c|}{ Compensation consultant market share } \\
\hline & \multirow{2}{*}{$\begin{array}{c}\text { OLS } \\
\text { Multiple } \\
\text { consultants }\end{array}$} & \multicolumn{2}{|l|}{ 2SLS } & \multirow{2}{*}{$\begin{array}{c}\text { OLS } \\
\text { Consultant } \\
\text { market share }\end{array}$} & \multicolumn{2}{|l|}{ 2SLS } \\
\hline & & $\begin{array}{l}\text { Equity-based } \\
\text { pay }\end{array}$ & Total pay & & $\begin{array}{l}\text { Equity-based } \\
\text { pay }\end{array}$ & Total pay \\
\hline & (1) & (2) & (3) & (4) & (5) & (6) \\
\hline Intercept & $\begin{array}{l}-1.438 * * * \\
(0.000)\end{array}$ & $\begin{array}{r}-0.817 \\
(0.386)\end{array}$ & $\begin{array}{l}4.062 * * * \\
(0.000)\end{array}$ & $\begin{array}{r}-5.687 \\
(0.168)\end{array}$ & $\begin{array}{r}-0.602 \\
(0.796)\end{array}$ & $\begin{array}{l}2.252^{* * * *} \\
(0.000)\end{array}$ \\
\hline Consultants & & $\begin{array}{l}1.201 * * \\
(0.032)\end{array}$ & $\begin{array}{l}0.546^{* * * *} \\
(0.001)\end{array}$ & & & \\
\hline Market share & & & & & $\begin{array}{c}0.429 * \\
(0.065)\end{array}$ & $\begin{array}{l}0.113 * * \\
(0.029)\end{array}$ \\
\hline Stock return & & $\begin{array}{l}1.119 * * * \\
(0.000)\end{array}$ & $\begin{array}{l}0.334 * * * \\
(0.001)\end{array}$ & $\begin{array}{r}0.338 \\
(0.562)\end{array}$ & & \\
\hline Firm size & $\begin{array}{l}0.092 * * * \\
(0.00)\end{array}$ & & & & $\begin{array}{r}0.025 \\
(0.853)\end{array}$ & $\begin{array}{l}0.074 * * \\
(0.021)\end{array}$ \\
\hline Firm risk & $\begin{array}{l}0.993 \text { *** } \\
(0.000)\end{array}$ & & & $\begin{array}{l}-3.542 * * \\
(0.012)\end{array}$ & & \\
\hline Board size & & $\begin{array}{l}2.384 * * * \\
(0.000)\end{array}$ & $\begin{array}{l}1.239 * * * \\
(0.000)\end{array}$ & & $\begin{array}{l}2.091 * * * \\
(0.002)\end{array}$ & $\begin{array}{l}0.885^{* * * *} \\
(0.000)\end{array}$ \\
\hline RemCo size & $\begin{array}{l}0.286^{* * * *} \\
(0.000)\end{array}$ & & & $\begin{array}{r}-0.556 \\
(0.257)\end{array}$ & & \\
\hline Non-executives & & & & & $\begin{array}{l}0.416^{* * *} \\
(0.042)\end{array}$ & $\begin{array}{l}0.118^{* * * *} \\
(0.000)\end{array}$ \\
\hline Institutional ownership & $\begin{array}{l}-0.015^{* * *} \\
(0.000)\end{array}$ & & & $\begin{array}{l}-0.117^{\star \star \star} \\
(0.000)\end{array}$ & & \\
\hline CEO duality & & $\begin{array}{l}-1.205^{* * * *} \\
(0.002)\end{array}$ & $\begin{array}{l}-0.464 * * * \\
(0.000)\end{array}$ & $\begin{array}{l}-1.012 * \\
(0.061)\end{array}$ & & \\
\hline CEO tenure & $\begin{array}{l}-0.032 * \\
(0.092)\end{array}$ & & & $\begin{array}{l}-0.240^{*} \\
(0.078)\end{array}$ & & \\
\hline CEO age & $\begin{array}{r}0.250 \\
(0.116)\end{array}$ & & & $\begin{array}{r}1.142 \\
(0.277)\end{array}$ & & \\
\hline Adj. $R^{2}$ & 0.13 & 0.09 & 0.17 & 0.03 & 0.08 & 0.28 \\
\hline
\end{tabular}

